\title{
LESSON 99
}

MARGINS: Pica, 20-70; Elite, Type this as many times as your teacher asks.

30-80.

Warm up

Clinic

Revise right shift key

Type each line 3 times.

Try to keep the $j k l$ fingers in position.

Improve Accuracy

25 wpm 6 minutes.

$\mathrm{A} 34-\mathrm{SI} 1.35$

Test your Skill

5 minutes.

MARGINS: Pica, 10-72; Elite, 15-85.

Keep the right margin as straight as possible.

Use double-line spacing.

$\mathrm{T} 21-\mathrm{SI} 1.29$

\section{UNIT 25/CONSOLIDATION LESSON 99}

1. The chimpanzee with the quaint coat on was an extremely clever animal. His tiny jacket was made of goat fur and had no buttons.

If you find difficulty in typing capital letters on the left hand practise stabbing down the right shift key with the little finger of the right hand.

2. Fast Dates Sink Andy Wend Rest Ever Tidy Cost Boil

3. Gain Coins True Baby Zinc Quip Vast Daze Work Rare

4. Town Wink Zeal Quay Cases Tail Gasp Bail Vase Sear

There are several forms of taxation and it is a lucky person indeed who escapes from having some tax to pay. If you buy some sweets for example it is certain that you have had to pay tax on them, a small amount agreed, but still tax. When you take your first pay packet or pay slip home, there will be a deduction from your pay called Income Tax. A stop at a shop to buy cigarettes, will result in a third tax being paid - one called Excise Duty.

Companies who make a profit, pay a tax called Corporation Tax in addition to a tax they, and any owner of property pay, Rates. Rates are a form of local tax and are based on the value of property.

There are three parties to a cheque, the bank who is ordered to make the payment, the person who is making the payment, and the person who is being paid the money. The bank is called the drawee the person making the payment is called the drawer and the person being paid is called the payee. If you take Commerce no doubt you learned all this in the lessons on banks and cheques.

Banks provide many services besides those you might use with one of the kinds of bank account be it a current account with the use of a cheque book and standing orders or the deposit account which a person who wanted interest on his money might use. Individuals may wish to use the bank paying-in and loan schemes while the business man might well use the night-safe or credit transfer schemes. Others may wish to use the bank card or the credit card.

To-day banks tend to widen their services and offer more than a safe place to keep cash. A bank is a place you could go to for advice on buying or selling stocks and shares, drawing up a will, tax, foreign markets, insurance and so on.

$9 \quad 10$

